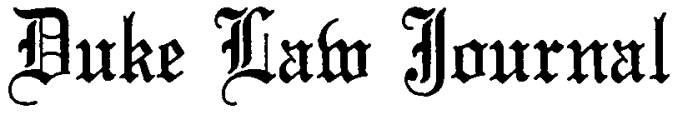

\section{THE PREEMPTION OF STATE LAW UNDER ERISA}

\section{WILLIAM J. KILBERG* AND CATHERINE L. HERON**}

I. INTRODUCTION.................................. 384

II. The Statutory Scheme ANd Purpose of ERISA...... 386

A. The Statute in Perspective ..................... 386

B. The Preemption Provision ...................... 389

C. The Legislative History of Section 514 ............ 390

III. Judicial ApPlication of Section $514 \ldots \ldots \ldots \ldots \ldots . . . .392$

A. Preemption of State Law Insofar as it Relates to Welfare Plans: Balancing Equity and Recognizing State Interests

1. Defining a "Plan" ......................... 392

2. Defining the Scope of Preemption and the "Saving" Clauses .................................... 394

B. Preemption of State Law "Insofar as it Relate[s] to" Retirement Plans: The Federal Interest in the Integrity of the Retirement Fund versus the State Interest in the Welfare of its Citizenry ........................... 403

- 1. The Uniqueness of Retirement Benefits: The PreERISA Federal Cases ....................... 403

2. The California Challenge: Community Property Principles for Allocating Spousal Rights ............. 405

* B.S. 1966, Cornell University; J.D. 1969, Harvard Law School; former Solicitor, United States Department of Labor, Member, District of Columbia and New York Bars.

** B.A. 1969, Wellesley College; J.D. 1972, Boston University School of Law; LL.M. Taxation, Georgetown University Law School; Member, Massachusetts and District of Columbia Bars.

THE FOLLOWING CITATION WILL BE USED IN THIS ARTICLE:

Employee Retirement Income Security Act of 1974, Pub. L. No. 93-406, 88 Stat. 829 (codified in scattered sections of $5,18,29,31,42$ U.S.C.) [hereinafter cited by session law sections of ERISA]. 
3. The New York Challenge: The Right to Support Becomes the Issue .............................. 410

4. The Problem for Plan Administrators and a Possible Resolution ............................... 414

IV. Conclusion ................................ 420

\section{INTRODUCTION}

The law of federal supremacy has never been very clear. It is a hornbook proposition that article VI of the Constitution ${ }^{1}$ mandates federal supremacy over state law where the law of the state "stands as an obstacle to the accomphishment and execution of the full purposes and objectives of Congress." 2 This may occur either when there is a clear conflict between state and federal law or when the state law infringes on an area specifically reserved by Congress for federal regulation. ${ }^{3}$ Congressional intent to occupy the field supersedes the operation of state law on the same subject matter without regard to whether actual conflict exists between the federal and state statutes. "When Congress has 'unmistakably . . . ordained' . . . that its enactments alone are to regulate a part of commerce, state laws regulatimg that aspect of cominerce inust fall." 4 Where the federal law is less clear, either because its language or its structure and purpose are uncertain, the state law inust still give way to the federal when

[t]he scheme of federal regulation [is] so pervasive as to make reasonable the inference that Congress left no room for the States to supplement it. . . . Likewise, the object sought to be obtained by the federal law and the charactcr of the obligations imposed by it may reveal the same purpose. ${ }^{5}$

Absent actual conflict between the operation of federal and state law, it is evident that the burden falls upon the judiciary to glean the intent of Congress in determining whether a particular subject matter has been federally preempted. ${ }^{6}$ In doing so, the courts must "start with the assumption that the historic police powers of the States were not to be superseded by the Federal Act unless that was the clear and mani-

1. This Constitution, and the Laws of the United States which shall be nade in Pursuance thereof; and all Treaties niade, under the Authority of the United States, shall be the suprente Law of the Land; and the Judges in every State shall be bound thereby, any Thing in the Constitution or Laws of any State to the Contrary notwithstanding.

U.S. ConsT. art. VI, cl. 2.

2. Hines v. Davidowitz, 312 U.S. 52, 67 (1941).

3. Florida Linue \& Avocado Growers, Inc. v. Paul, 373 U.S. 132, 142 (1963). See also Jones v. Rath Packing Co., 430 U.S. 519, 534 (1977).

4. Jones v. Rath Packing Co., 430 U.S. 519, 525 (1977).

5. Rice v. Santa Fe Elevator Corp., 331 U.S. 218, 230 (1947).

6. Rogers v. Larsen, 563 F.2d 617, 621 (3d Cir. 1977), cert. denied, 435 U.S. 966 (1978). 
fest purpose of Congress." In meeting its constitutional mandate, the Supreme Court has relied more on its own attitude toward federal-state relationships than on any consistent application of legal doctrine. At different times in its history, the Court has variously described the starting point for applying the supremacy principle. Tlie Warren Court focused on the federal scheme, Chief Justice Warren himself writing: "The relative importance to the State of its own law is not material when there is a conflict with a valid federal law, for the Framers of our Constitution provided that the Federal law must prevail." Court, however, has described the doctrine of federal supremacy in different terins:

If Congress is authorized to act in a field, it should manifest its intention clearly. It will not be presumed that a federal statute was intended to supersede the exercise of the power of the state unless there is a clear manifestation of intention to do so. The exercise of federal supremacy is not hightly to be presumed. ${ }^{9}$

The most difficult preemption questions arise where the state and federal laws are aimed at different subject matters, but where the application of state law impinges upon a congressionally stated desire to insure a uniform federal regulatory scheme of a particular area of commerce. As the Court noted in Farmer v. United Brotherhood of Carpenters, ${ }^{10}$ "inflexible application of the [preemption] doctrine is to be avoided, especially, where the State has a substantial interest in regulation of the conduct at issue and the State's interest is one that does not threaten undue interference with the federal regulatory scheme."11

On Labor Day, 1974, the Employee Retirement Income Security Act (ERISA) became law. ERISA imposed a comprehensive scheme of federal regulation on employee benefit plans, as defined im the Act. ERISA supersedes all state laws "imsofar as they relate to" such employee benefit plans, with the exception of state laws regulating banking, securities or imsurance. ${ }^{12}$

Although the broad language of section 514, ERISA's preemption provision, may appear quite clear upon superficial examination, the law concerning the extent of ERISA's preemption of state laws remains unsettled. The definition of employee welfare benefit plans, ${ }^{13}$ and the

7. Rice v. Santa Fe Elevator Corp., 331 U.S. at 230.

8. Free v. Bland, 369 U.S. 663,666 (1962).

9. New York State Dep't of Social Serv. v. Dublino, 413 U.S. 405, 413 (1973) (citing Schwartz v. Texas, 344 U.S. 199, 202-03 (1952)).

10. 430 U.S. 290 (1977).

11. Id. at 302 .

12. ERISA $\S 514$ (codified at 29 U.S.C. $\$ 1144$ (1976)).

13. See notes $22,47-55$ infra and accompanying text. 
interaction of ERISA with state pregnancy disability ${ }^{14}$ and insurance laws ${ }^{15}$ have caused continuing controversy concerning the regulation of welfare benefit plans. ERISA's regulation of pension plans creates possible conflicts between ERISA and state community property laws ${ }^{16}$ or state enforcement of support obligations. ${ }^{17}$ The effect of ERISA on such state laws, which are not aimed specifically at employee benefit plans and which operate in traditional areas of state imterest, inust be clarified.

The regulatory scheme of ERISA refiects a congressional dcsire to provide a uniform federal approach to the regulation of employee benefit plans. Thus, an analysis of ERISA's preemption of the application of particular state laws requires both an understanding of congressional purpose and an appreciation of the extent to which a state interest is of sucli traditional importance as to permit it to disrupt the congressional design. This Article will examme the congressional purpose and intent of ERISA as revealed through statutory langnage and legislative history and will discuss the problem areas noted above in light of the judicial interpretation of section 514 .

\section{The Statutory Scheme and Purpose of ERISA}

\section{A. The Statute in Perspective.}

ERISA, the culmination of many years of congressional and executive consideration, ${ }^{18}$ has three major purposes. In addition to "assuring the equitable cliaracter of [employee benefit] plans and their financial soundness," ${ }^{19}$ ERISA fosters and protects the growth of such plans. ${ }^{20}$

ERISA achieves the first two objectives through a complex and lengthy statutory scheme that imposes differing burdens on pension ${ }^{21}$

14. See notes 57-66 infra and accompanying text.

15. See notes $56,70-94$ infra and accompanying text.

16. See notes 104-34 infra and accompanying text.

17. See notes $135-63$ infra and accompanying text.

18. A number of predecessor bills were introduced in Congress in the years prior to enactment of ERISA. The following bills were introduced in 1973 and 1974 before the passage of both a Senate version of H.R. 2 and a House version of H.R. 2, which were submitted to the Conference Committee in the spring of 1974: S. 1631, 93d Cong., 1st Sess. (1973); S. 1557, 93d Cong., 1st Sess. (1973); S. 1179, 93d Cong., lst Sess. (1973); S. 4, 93d Cong., 1st Sess. (1973); H.R. 12906, 93d Cong., 2d Sess. (1974); H.R. 12855, 93d Cong., 2d Sess. (1974); H.R. 9824, 93d Cong., lst Sess. (1973); H.R. 4200, 93d Cong., 1st Sess. (1973); H.R. 462, 93d Cong., Ist Sess. (1973); H.R. 2, 93d Cong., Ist Sess. (1973).

19. 29 U.S.C. $\$ 1001$ (a) (1976).

20. See notes 32-34 infra and accompanying text.

21. Pension plans subject to ERISA include

any plan, fund, or progran which was heretofore or is hereafter established or maintained by an employer or by an employee organization, or by both, to the extent that by 
and welfare plans. ${ }^{22}$ Pension plans covered by ERISA are subject to detailed statutory requirements including reporting and disclosure to plan participants and beneficiaries, ${ }^{23}$ minimum plan standards for eligibility to participate and for vesting, ${ }^{24}$ minimum funding standards, ${ }^{25}$ and standards of conduct for persons who serve in a fiduciary capacity to a plan. ${ }^{26}$ This extensive scliene of regulation is enforced by three federal agencies-the Department of Labor, the Internal Revenue Service and the Pension. Benefit Guaranty Corporation-pursuant to a plan of enforcement whicl is soinetimes botll interrelated and overlapping. ${ }^{27}$ In contrast to the detailed regulation of pension plans under ERISA, welfare plans are regulated only by the Department of Labor pursuant to the provisions of Title I of ERISA. ${ }^{28}$ The reporting and disclosure requirements of Part I and fiduciary responsibility standards of Part IV are, in effect, the only substantive statutory requirements imposed on welfare plans covered by ERISA. ${ }^{29}$

its express terms or as a result of surrounding circumstances such plan, fund or program-

(A) provides retirement income to employees, or

(B) results in a deferral of income by employees for periods extending to the termination of covered einployment or beyond, regardless of the method of calculating the contributions made to the plan, the method of calculating the benefits under the plan or the method of distributing benefits from the plan.

ERISA § 3(2) (codified at 29 U.S.C. § 1002(2) (1976)).

22. Welfare plans subject to ERISA include

any plan, fund, or program which was heretofore or is hereafter established or maintamed by an employer or by an einployee organization or by both, to the extent that such plan, fund, or program was established or is maintained for the purpose of providing for its participants or their beneficiaries, through the purchase of insurance or otherwise, (A) medical, surgical, or hospital care or benefits, or benefits in the event of sickness, accident, disability, death or unemployment, or vacation benefits, apprenticeship or other training programs, or day care centers, scholarship funds, or prepaid legal services, or (B) any benefit described in section 302(c) of the Labor Management Relations Act, 1947 (other than pensions on retirement or death, and insurance to provide such pensions).

ERISA \& 3(1) (codified at 29 U.S.C. \& 1002(1) (1976)).

23. ERISA $\$ \$ 101-111$ (codified at 29 U.S.C. $\$ \$ 1021-1031$ (1976)); cf. I.R.C. $\$ 8057-6059$ (pension plan registration requiremeuts).

24. ERISA $\S \S 201-211$ (codified at 29 U.S.C. $\S \S 1051-1061$ (1976)); I.R.C. $\S \S 410-411$ (minimum participation standards for plans qualifying under I.R.C. $\$ 401$ (a)).

25. ERISA $\S \S 301-306$ (codified at 29 U.S.C. $\S \S 1081-1086$ (1976)); I.R.C. $\S 412$ (mininium funding standards for plans qualifyimg under I.R.C. $\$ 401(a)$ ).

26. ERISA $\S \S 401-414$ (codified at 29 U.S.C. $\$ \S 1101-1114$ (1976)).

27. See Title III of ERISA (codified at 29 U.S.C. $\$ 1201-1204$ (1970)), which sets out the statutory scheme of enforcement responsibilities, and the recently enacted Reorganization Plan No. 4 of 1978, 43 Fed. Reg. 47713 (1978).

28. Pursuant to the recently enacted Revenue Bill of 1978, Pub. L. No. 95-600, 92 Stat. 2763 certain "cafeteria" plans, which offer employees a choice of one or more of a number of taxable or nontaxable benefits, will be required to meet certain non-discrimination standards under the Code.

29. Welfare plans are specifically exempted from the participation, vesting and funding standards established for pension plans. ERISA $\$ \S 201(1), 301$ (a)(1) (codified at 29 U.S.C. $\$ \S 1051(1)$, 1081(a)(1) (1976)). 
ERISA serves its third purpose, to foster and protect the growth of employee benefit plans, through the positive inducement of tax advantage and the negative mducement of avoidance of multitudinous state laws. ERISA enhanced provisions in the Internal Revenue Code of 1954, as ainended (the Code), which provide for a current deduction for employer contributions to a qualified pension $\operatorname{plan}^{30}$ and for deferred taxation of employees on amounts contributed on their behalf. ${ }^{31}$ These positive tax incentives were clearly designed by Congress to encourage the growth and maintenance of private pension plans, ${ }^{32}$ as was pointed out in a committee report on one of the predecessor bills to ERISA:

In broad outline, the objective is to increase the number of individuals participating in employer-financed plans ....

Essentially your committee's bill represents a significant improveinent in the tax treatment now applicable with respect to quahfied retireinent plans. Your committee regards the present legislation as part of an evolutionary process which keeps this basic framework but which builds upon it new provisions which experience indicates are necessary for proper functioning of the plans. ...

... The committee bill also continues the approach in present law of encouraging the establishment of retireinent plans which contain socially desirable provisions through the granting of tax inducements. ${ }^{33}$

The broad preemption of state law in section 514 of ERISA also plays a critical role in the congressional design to foster and protect the growth of private employee pension and welfare plans. Einployers and plan administrators are assured of uniform federal regulation rather than being subjected to the inyriad of state laws which could be applied to an employer maintaining a plan for employees who are located in several different states. Senator Javits noted the importance of the umform federal regulation which was intended by the breadth of section 514:

[T]he einergence of a comprehensive and pervasive Federal interest

30. I.R.C. $\$ 404$.

31. Id. $\S 402$.

32. As Congressman Ullman stated on the floor of the House during the debates prior to the enactment of ERISA,

I want to emphasize that the new requirements have been carefully designed to provide adequate protection for employees and at the same time, provide a favorable setting for the growth and development of private pension plans. It is axiomatic to anyone who has worked for any time in this area that pension plans cannot be expected to develop if costs are made overly burdensome, particularly for employers who generally foot most of the bill. This would be self-defeating and would be unfavorable rather than helpful to the employees for whose benefit this legislation is designed. For this reason, we have been extremely careful to keep costs very moderate.

120 CoNG. REC. 29198 (1974).

33. H.R. Rep. No. 779, 93d Cong., 2d Sess. 8 (1974). 
and the interests of uniformity with respect to interstate plans required . . . the displacenent of State action in the field of private employee benefit prograins.

It is also intended that a body of Federal substantive law will be developed by the courts to deal with issues involving rights and obligations under private welfare and pension plans. ${ }^{34}$

\section{B. The Preemption Provision.}

ERISA includes in section 514(a) an expansive and seemingly clear preeinption of state regulation:

Except as provided in subsection (b) of this section, the provisions of this subchapter ["Protection of Employee Benefit Rights"] and subchapter III ["Plan Termination Insurance"] of this chapter shall supersede any and all State laws insofar as they may now or liereafter relate to any employee benefit plan described in Section 1003(a) . . . and not exempt under Section 1003(b) . . . .35

On a closer reading, however, section 514 reveals uncertainties as to the scope of its effect on particular state laws and as to the types of einployee benefit arrangeinents to which it apphies. While the phrase "insofar as" implies the potential preemption only of particular applications of state law, the phrase "relate[s] to" implies preemption of the state law itself. Preemption may be asserted, moreover, only with respect to an "einployee benefit plan" covered under Title I, and thus does not apply to any einployee benefits arrangement specifically excluded from coverage or to other arrangements which may resemble einployee benefit plans im only some respects. Thus, even on its face, section 514 hints at the complexity of its interpretation.

The language of section 514 specifically "saves" from preemption state laws regulating insurance, banking or securities. Section 514(b)(2)(A) states that "[e]xcept as provided in subparagraph (B), nothing in this subchapter sliall be construed to exempt or relieve any person from any law of any State which regulates msurance, banking, or securities." 36

To prevent this saving provision from developing into a loophole through the characterization of plans as insurance providers, banks or bank investment companies, section 514(b)(2)(B) includes a prohibition against plans being so deemed:

Neither an employee benefit plan described in section 1003(a) of this title, which is not exempt under section 1003(b) of this title (other than a plan established primarily for the purpose of providing death

34. 120 CONG. REC. 29942 (1974).

35. 29 U.S.C. \& 1144 (1976).

36. Id. \& $1144(\mathrm{~b})(2)(\mathrm{A})$. 
benefits), nor any trust establislied under sucli a plan, sliall be deemed to be an imsurance company or other insurer, bank, trust company, or investment company or to be engaged in the business of imsurance or banking for purposes of any law of any State purporting to regulate insurance compames, insurance contracts, banks, trust compamies, or investment compames. ${ }^{37}$

With respect to ERISA's relationship to other federal laws, section 514 contains a specific denial of any preemption:

Nothing in this subchapter shall be construed to alter, amend, modify, invalidate, impair, or supersede any law of the United States (except as provided in sections 1031 and $1137(\mathrm{~b})$ of this title) or any rule or regulation issued under any such law. ${ }^{38}$

\section{The Legislative History of Section 514.}

Congress deliberately chose the broad preemption language of ERISA's section 514, rejectimg the narrower scope of preemption proposed in earlier versions of the law. Prior versions limited federal preemption to the substantive areas actually regulated under the legislation and to the state laws relating to the type of plan (welfare or pension) covered within a particular area of the federal regulation. ${ }^{39}$

The crucial cliange adopted by the Congress was the preemption of state laws relating to plans covered by ERISA as opposed to subjects covered by the Act. Section 514, in its final form, resulted in a preemption of state law insofar as it may relate to employee benefit plans, and not merely a preemption of state law affecting the specific aspects of benefit plans which Congress has undertaken to regulate.

The intent of Congress in adopting the present language of section 514 was described in explicit and expansive terms in statements by the bill's inanagers prior to enactment. Congressman Dent declared:

Finally I wish to make note of what is to many the crowning achievement of this legislation, the reservation to Federal authority [of] the sole power to regulate the field of employee benefit plans. With the preemption of the field, we round out the protection afforded participants by eliminatimg the threat of conflicting and inconsistent State and local regulation. ...

The conferees, with the narrow exceptions specifically enumerated, apphed this principle in its broadest sense to foreclose any nonFederal regulation of employee benefit plans. Thus, the provisions of section 514 would reach any rule, regulation, practice or decision

37. Id. § $1144(\mathrm{~b})(2)(\mathrm{B})$.

38. $I d . \S 1144(\mathrm{~d})$.

39. See, e.g., S. 4, 93d Cong., Ist Sess. §609(a) (as introduced Jan. 4, 1973); H.R. 2, 93d Cong., 1st Sess. $§ 699$ (as passed by the Senate on Mar. 4, 1974); id. $\S 514$ (as passed by the House on Feb. 28, 1974); H.R. 4200, 93d Cong., Ist Sess. $\$ 699$ (as passed by the Senate on Sept. 19, 1973); H.R. 2, 93d Cong., Ist Sess. $§ 14$ (as introduced Jan. 3, 1973). 
of any State, subdivision thereof or any agency or instrumentality thereof... which would affect any employee benefit plan as described in section 4(a) and not exempt under section 4(b). ${ }^{40}$

The preemption of state laws that, im Congressman Dent's words, "affect any employee benefit plan" expresses a broad intent to preempt the field. It would be a mistake, however, to view statements like those of Congressman Dent as conclusive evidence of congressional imtent without considering the context in which they were made and the overall thrust of what the Congress was attempting to achieve.

The full impact of the conference changes may not have been recognized by Congress. The final preemption language was a product of the House-Senate Conference Committee, ${ }^{41}$ not the usual forum for congressional deliberation, and has the effect of reversing the language of both Senate and House bills. Even assuming that most of those who voted for ERISA's passage ${ }^{42}$ understood and supported the broad preemption approach, it is not clear whether the Congress fully appreciated the differences in ERISA's regulatory scheme regarding pension and welfare plans, ${ }^{43}$ the import of the saving clauses for state imsurance, banking and securities laws, ${ }^{44}$ or the definitional exclusions for state disability, workmen's compensation and unemployment laws. ${ }^{45}$ ERISA's limited regulation of welfare plans and broad preemption provision presented the opportunity for a regulatory vacuun im this area. However, Congress may have assumed that the proviso in section 514(b)(2)(A) and the definitional language in section 514(a) sufficiently removed any concern regarding the creation of a regulatory vacuum which might otherwise result from federal preemption of state laws relating to welfare plans.

Nevertheless, it is still quite clear that Congress wished to protect plans subject to ERISA from the additional burden of varying and possibly conflicting applications of state law. At the same time, there is no doubt that Congress mtended to preserve some apphications of state law in areas that are traditional subjects of state action-imsurance, banking, securities, workmen's compensation, disability and uneinployment programs. It fell to the courts to apply this mixed intent to the enor-

40. 120 Cong. REC. 29197 (1974).

41. When a comparison is made between the bills passed by both the House and Senate, it can be seen that the present language was drafted by the Conference Committee. See SrafF Conference Comm. on H.R. 2,93D Cong., 1st Sess., Summary of Differences Between the Senate Version and the House Version of H.R. 2, pt. 3, 23-33 (Comm. Print 1974).

42. ERISA was passed by an overwhelming majority in both the House and Senate. The Senate vote was unanimous and there were only two dissenting votes in the House.

43. See discussion in text accompanying notes 21-29 supra.

44. ERISA \& 514(b)(2)(A) (codified at 29 U.S.C. \& 1144(b)(2)(A) (1976)).

45. ERISA § 514(a) (codified at 29 U.S.C. \& 1144(a) (1976)). 
mous variety of employee benefit plans and the myriad of state laws that relate to them im a host of different ways. In carrying out this responsibility the courts must apply congressional intent with due regard for the sometimes elusive standards of federal supremacy.

\section{Judicial Application of Section 514}

\section{A. Preemption of State Law Insofar as it Relates to Welfare Plans. Balancing Equity and Recognizing State Interests.}

1. Defining a "Plan." Before section 514 can be said to preempt state law or an application of such law the plan affected must be an "employee benefit plan," as defined in sections 4(a) and (b) of the Act. ERISA's coverage definitions are purposely vague and broad, carving out limited exceptions rather than attempting to delineate the exact scope of coverage. ${ }^{46}$

The case of multiple employer trusts (METs), also referred to as employee security benefit associations (ESBAs), ${ }^{47}$ exemplifies the balancing approach taken by the courts in distinguishing between a state law which relates to a plan and a state insurance law. If METs are viewed as employee benefit plans rather than as insurance providers, section 514 would preempt any state attempt to regulate such arrangements. Self-funded METs ${ }^{48}$ lack the contingency reserves of insurance companies. Because ERISA does not regulate the funding of welfare plans, a MET which is not subject to state insurance regulation is virtually unregulated. Thus a broad interpretation of the definition of employee welfare benefit plans, including METs, could prevent state regulation in areas where there is no federal substitute.

46. See ERISA $\S \S 3(1)-(2)$ (codified at 29 U.S.C. $\S \S 1002(1)-(2)$ (1976)), quoted in notes 2122 supra, and the regulations thereunder at 29 C.F.R. $\$ \S 2510.3-1,2510.3-2$ and 2510.3-3 (1977).

47. Under a MET a number of otherwise unrelated small employers typically join together to provide benefits, whether insured or uninsured, which are similar to those offered by larger enployers. A third party administrator is frequeutly used as a vehicle through which employer contributions may be pooled. The court in Bell v. Employee Security Benefit Ass'n, 437 F. Supp. 382 (D. Kan. 1977) cited a number of factors that distinguish a MET from an employee benefit plan, such as the absence of an employer-employee relationship, a profit motive and solicitation. An employee benefit plau, unlike a MET, is provided by an employer, a union or a jomt board of trustees, is noncommercial in nature and is not promoted by public solicitatiou.

48. Under a fully insured MET, ERISA's preemption of state regulation would not have the same potential for adverse effects for participants as would preemption of state regulation in the case of a self-funded plan. Participants in a fully insured plan would still be afforded some protection from loss despite the immmity of the MET from state regulation. A fully insured MET would be funded by an insurance contract which would normally be subject to state regulation of reserves and underwriting practices. On the other hand, a self-funded MET which is not subject to any state regulation would not provide the same protections because of the absence of any substantive funding or reserve requirements for welfare plans covered by ERISA. 
In Bell v. Employee Security Benefit Association ${ }^{49}$ the court both recognized and reaffirmed the breadth of section 514, while limiting its apphication to arrangeinents of this kind. Concerned that section 514 might result in the creation of a regulatory vacuum, the court stated that "[o]ur conclusion is that just as a state cannot regulate an 'employee benefit plan' by calling it 'insurance,' neither can defendants merchandise an insurance prograin, free of state regulation, by terming it an "employee benefit plan." "50 The court in Bell identified the characteristics of an ESBA and distinguished them from the characteristics of an employee benefit plan, concluding that the "ESBA is marketing disguised insurance." 51 The facts in Bell, particularly the absence of employer participation and the entrepreneurial nature of the ESBA, lend credence to the court's approach. Through this "facts and circuinstances" approach to the definition of an einployee benefit plan, the court balanced the broad congressional statement of preenption im section 514 and the need to preserve state primacy in an area not adequately regulated by ERISA. ${ }^{52}$

In Wayne Chemical, Inc. v. Columbus Agency Service Corp. ${ }^{53}$ the Federal District Court for the Northern District of Indiana held that a MET was a plan, not an insurance provider, thereby rendering state laws regulatimg imsurance impotent as to the MET. In that case, an

49. 437 F. Supp. 382 (D. Kan. 1977).

50. Id. at 390 .

51. Id. at 392. For other cases which dealt with the issue of METs see Hamberlin v. VIP Insurance Trust, 434 F. Supp. 1196 (D. Ariz. 1977) and NBCEBA v. Howatt, [1978] 179 PENs. ReP. (BNA) D-4 (D. Ore. 1977). The courts in both Hamberlin and Howatt found that the METs in question were not employee benefit plans covered by ERISA and were, therefore, subject to state insurance regulation. In Howatt the court noted that the National Business Conference Employee Benefit Association was essentially the same program as that cousidered by the court in Bell. The absence of a commonality of employment status among the covered members of the association resulted in a finding that these associations or METs were not ERISA-covered employee benefit plans. In Hamberlin the court found that the VIP multiple employer trust, which had origimally been fully insured but subseqnently became self-insured, was an entrepreneurial enterprise operated for profit and was not an employee benefit plan. The court noted that the insurance brokers who had origmally established the plan converted it to a self-insured trust after the insurance coinpany had cancelled its coverage so that they (the brokers) could contimue to receive their commissions. As in Bell and Howatt, the court found that an entrepreneurial profitmaking arrangement which provided benefits to a group of unrelated employees was not the type of arrangement Congress had intended to include within the definition of an employee benefit plan.

52. The court was aided in its analysis by a report of the House ERISA Oversight Task Force which concluded that METs "are not established or maimtaimed by the appropriate parties to confer ERISA jurisdiction, nor is the purpose for their establishment or mamtenance appropriate to ineet the jurisdictional prerequisites of the Act." Activitr REPORT OF THE COMMITTEE ON Education and Labor of the U.S. House of Representatives, H.R. Rep. No. 1785, 94th Cong., 2d Sess. 48 (1976).

53. 426 F. Supp. 316 (N.D. Ind.), affd, 567 F.2d 692 (7th Cir. 1977). 
employer, Wayne Chemical, purchased a group medical insurance policy for its employees from the Columbus Agency Service Corporation (CASCO), which was agent for the National Multiple Employee Foundation (NMEF), a MET, and Association Life Insurance Company. The policy, originally underwritten by Association Life, was later transferred from the insurance company to the MET. An employee of Wayne Chemical filed a claim under the policy on behalf of his 18-year old son, who had suffered mjuries requiring extensive medical care for an extended period, and was told that benefits would terminate on his son's twentieth birthday. Indiana state imsurance law prohibited such termination. By finding that the MET in question was an ERISA-covered employee benefit plan, lowever, the court effectively preempted the application of state imsurance law. The court avoided the unfortunate result which such a finding demanded by adopting the applicable provision of the Indiana state insurance law as federal common law. ${ }^{54}$ Thus, coverage contimued and the regulatory vacuum created by section 514 was filled.

The Seventh Circuit affirmed the district court's lolding in Wayne Chemical, ${ }^{55}$ but on different grounds. The Seventh Circuit found that the employer, Wayne Chemical, Inc., never subscribed to an employee benefit plan as such, but merely sought to purcliase msurance to provide the benefits promised to its employees. Although an NMEF "Plan and Trust Agreement". existed, it was unsigned and there was no credible evidence of its involvement in the employer's insurance transaction. Thus, NMEF sold imsurance directly to the employer, not to an employee benefit plan, and it was the msurance contract, not the terms of an employee benefit plan, which contamed the provisions offensive to Indiana law. By so constituting the facts, the court was led to hold first, that the medical coverage provided to Wayne Chemical's employee was not provided by an employee benefit plan and second, that the applicable Indiana law prohibiting termination of coverage was an insurance law saved from preemption by section 514(b)(2)(A) of ERISA. By construing the transaction as a simple sale of insurance the Seventh Circuit avoided the necessity of formulating federal common law to fill in the regulatory void that would have been caused by preemption.

2. Defining the Scope of Preemption and the "Saving" Clauses. Having determined whether a particular benefit program is an employee benefit plan under ERISA, a court must next decide whether the state law in question "relates to" the employee benefit plan and, if it

54. Id. at 325 .

55. 567 F.2d 692 (7th Cir. 1977). 
does, whether it is a law regulating insurance, banking or securities so as to be saved from federal preemption. ${ }^{56}$

The issue of whether a state law or a particular application of a state law relates to an employee benefit plan so as to be preempted by ERISA has been raised in several decisions that have upheld provisions of state equal employment opportunity laws requiring coverage of pregnancy under employers' disability plans. In Time Insurance Co. $v$. Department of Industry, Labor and Human Relations ${ }^{57}$ a Wisconsin court found the Wisconsm Fair Employment Law sex discrimination provisions to be "merely of peripheral concern of ERISA" ${ }^{38}$ and held that ERISA does not preempt the state law "until the United States Supreme Court rules to the contrary." 59 The court's decision did not engage in any analysis of ERISA's preemption language, and relied primarily on the state's broad police power to prevent employers from engaging in any employment practice which discriminates on the basis of sex.

A federal district court in Wisconsin similarly upheld the Wisconsin Fair Employment Act against a challenge of ERISA preemption in Bucyrus Erie Co. v. Department of Industry, Labor and Human Relations. ${ }^{60}$ With little analysis of ERISA's preemption provisions, the court found that a presumption in favor of the state's historic police powers had not been overcome by ERISA's regulation of employee benefit plans, an area which is separate from, although sometimes overlapping, the area regulated by the state's fair employment law. The court traced the development of federal preemption and concluded, like the Burger Supreme Court, that "it is clear that state statutes are presumed to be valid unless Congress clearly intended these statutes to be superseded by federal law." 61 With respect to ERISA's preemption of a state's fair employment law, the court pointed out that "[t]he legislative history of the Act fails to indicate that Congress, by enacting ERISA, intended to preempt state fair employment laws as they may concern employee benefit plans." 62

In a third decision, Lukus v. Westinghouse Electric Corp. ${ }^{63}$ a Penn-

56. For an early but thoughtful discussion of ERISA's "relates to" language and the insurance proviso and their effect on state insurance laws see generally Brummond, Federal Preemption of State Insurance Regulation Under ERISA, 62 IowA L. REv. 57 (1976).

57. [1978] 174 Pens. Rep. (BNA) D-9 (Cir. Ct., Dane County, Wis. 1978).

58. Id. at $\mathrm{D}-12$.

59. Id.

60. [1978] 198 PeNs. Rep. (BNA) D-7 (E.D. Wis. 1978).

61. Id. at $\mathrm{D}-8$.

62. Id.

63. No. GD 77-14803, slip op. at 7 (Pa. Ct. C.P. Apr. 20, 1978). 
sylvania state court held that ERISA does not preempt Pennsylvania's Human Relations Act, ${ }^{64}$ which prohibits sex-based discrimination under an employer's disability plan. The court reasoned "that ERISA was intended to guarantee uniform administration of the regulation and operation of eniployee benefit plans and not the content thereof." 65

These opinions do not engage in extensive analysis of ERISA's preemption language or the "relates to" limitation; rather they rest their arguments on strongly held notions of state primacy in matters involving the broad police power to prevent discriminatory employment practices. By denying preeniption of a state statute which regulates the substantive coverage of an eniployer's disability plan, these decisions would narrow ERISA's scope of preeinption. ${ }^{66}$ It may well be that the Congress, when it enacted ERISA, was unaware of the reach of section 514. As indicated above, ${ }^{67}$ at least with regard to welfare plans, Congress may not have appreciated the full potential of its decision to "supersede any and all State laws insofar as they may now or hereafter relate to any employee benefit plan" 68 covered by ERISA and not otherwise specifically saved from preemption. However, the statutory language is clear and the legislative history supports its broad scope of preemption.

Although it is appropriate for the courts to balance a state's interest in maintaining its traditional police powers against the federal imterests served by a federal statute as described in its legislative history, these decisions do not properly balance the state and federal interests. They fail to recognize and describe properly the intent of Congress in

64. 43 PA. Cons. STAT. $\S \S 951-62$ (Supp. 1978).

65. No. GD 77-14803, slip op. at 7. In addition to the argument that state fair employment laws do not relate to employee benefit plans within the meaning of $\S 514$, the court in Westinghouse Electric found that preemption would violate § 514(d), which provides that ERISA is not to impair the operation of any other federal statute. The Court found that the creation of the state's fair employment law, 43 PA. Cons. STAT. $\$ \S 951-62$ (Supp. 1978) is implicitly recognized under Title VII of the Civil Rights Act of 1964, 42 U.S.C. $\$ \S 2000$ e to 2000e-17 (1976). The court reasoned that ERISA's preemption of the state's equal employment law would "in effect inake Title VII's mandatory 60 day deferral to state fair employment laws meaningless," No. GD 77-14803, slip op. at 7, and would obhiterate the "Congressional mandate that the EEOC cooperate with state agencies and accord substantial weight to their findings and orders." Id.

66. But see Mountain States Tel. and Tel. Co. v. Commissioner of Labor and Indus., [1978] 210 Pens. Rep. (BNA) D-1 (Mont. Dist. Ct. 1978). In that case the court held that ERISA preempts the state statute dealing with maternity leave policies. The Montana court rested its decision on the congressionally stated need for uniform regulation of multistate employee benefit plans such as the Mountain Bell welfare plan. Accord, Pervel Indus., Inc. v. Connecticut Comm'n on Human Rights and Opportumities, Civil No. H-78-459 (D. Conn. 1978) (ERISA preempts Connecticut's anti-discrimination law insofar as it requires the imclusion of preguancy disability benefits under an ERISA covered welfare plan).

67. See text accompanying notes 41-45 supra.

68. ERISA § 514 (codified at 29 U.S.C. § 1144 (1976)). 
enacting section 514 of ERISA. The state interest inust be balanced against the intent of Congress as reflected in the language of the federal statute. Absent a reasonable construction of that language and its legislative history which leaves room for state action, the federal law must be found to be supreme.

There may be rooin for state action regarding pregnancy disability laws; however, the statutory language and legislative history of section 514 do not provide a clear guide as to congressional intent with respect to such laws. Section 514(a) saves from preemption a state law that relates to an einployee benefit plan described in section 4(b). Section 4(b)(3) provides that ERISA does not apply to plans maintained solely for the purpose of coinplying with state disability insurance laws. ${ }^{69}$ Therefore, the description given to a particular state law could be critical. For example, ERISA would not preempt a state disability insurance law imposing substantive coverage requirements, such as pregnancy disability coverage, on an einployee welfare benefit plan inaintained to coinply with that insurance law; the plan is excluded from ERISA's coverage definitions by section 4(b). On the other hand, a state's equal employment opportunity law, which imposes certain pregnancy disability coverage requirements on einployers within the state, could be preempted as a state law that relates to employee benefit plans. Congress must clarify its intent in this area to enable the courts to balance correctly the federal and state interests.

In contrast to the pregnancy disability decisions, the federal court rulings that have addressed the scope of ERISA's saving clause for state insurance, banking and securities laws contain a inore detailed analysis of the scope of preenption, underscoring more forcibly the need for congressional clarification.

In Hewlett-Packard Co. v. Barnes, ${ }^{70}$ the District Court for the Northern District of California held that ERISA preempted California's Knox-Keene Health Care Service Plan Act. ${ }^{71}$ The Knox-Keene Act's provisions sought, annong other things, to expand upon ERISA's regulation of employee benefit plans in such areas as funding, disclosure, sales practices and the quality of services provided. Thus the Knox-Keene Act directly infriniged on areas exphcitly regulated by ERISA, and did not require the court to adopt an expansive view of the scope of ERISA's preeinption. Judge Renfrew dismissed the state's contention that the phrase "relates to" in section 514 is either "vague"

69. 29 U.S.C. \& $1003(b)(3)$ (1976).

70. 425 F. Supp. 1294 (N.D. Cal. 1977), affd, 571 F.2d 502 (9th Cir.), cert. denied, 99 S. Ct. 108 (1978).

71. Cal. Health \& SafeTy Code $\$ \$ 1340-1345$ (West Supp. 1978). 
or "ambiguous": "[T]he Court doubts that Congress could have chosen any more precise language to express its intent to preempt a state statute such as Knox-Keene msofar as it seeks to regulate ERISA covered employee benefit plans such as those maintamed by plaintiffs."72

The Ninth Circuit affirmed Judge Renfrew's decision in HewlettPackard. ${ }^{73}$ After concluding that the scope of ERISA's "relate[s] to" language must be at least broad enough to preempt a state statute which imposes regulatory standards in the areas covered by ERISA, the court held that ERISA's preemption of the Knox-Keene Act would not impair other federal legislation in violation of section 514(d) of the Act. With respect to the Health Mamtenance Organization Act ("HMO Act") ${ }^{74}$ the court stressed that ERISA preempts the KnoxKeene Act only imsofar as it applies to einployee benefit plans, not liealth maintenance organizations. Thus, preemption under section 514 would not interfere with the concurrent state and federal regulatory scheme envisioned under the HMO Act. Similarly, the court rejected appellant's argument that preeinption interfered with the McCarranFerguson Act, ${ }^{75}$ which requires that ERISA or any federal law not be construed in a maimer whicl violates the policy of reserving to the states the authority to regulate insurance unless that federal law "specifically relate[s]" to insurance. ${ }^{76}$ The court noted that sections of ERISA undeniably do relate specifically to the business of insurance. ${ }^{77}$ The court also reasoned that ERISA's deemer clause, "which states that an employee benefit plan shall not be deemed to be engaged in the busimess of msurance," prevented any conflict with the McCarran-Ferguson Act. ${ }^{78}$ The court thus rejected the challenge to ERISA preemption based on the section 514(d) prohibition agamst the impairment of any other federal law.

Judge Renfrew, in Standard Oil Co. of California v. Agsalud, ${ }^{79}$ adopted an expansive interpretation of ERISA's preemption, not limiting it to those state laws that directly affect areas regulated by ERISA. The court held that Hawaii's Prepaid Health Care Act $^{80}$ was preempted by ERISA. Although the Hawaii statute, whicli required that workers in the state be covered by a comprehensive prepaid healtl care plan,

\footnotetext{
72. 425 F. Supp. at 1297.

73. 571 F.2d 502 (9th Cir.), cert. denied, 99 S. Ct. 108 (1978).

74. 42 U.S.C. $\S \S 300 \mathrm{e}$ to $300 \mathrm{e}-15$ (1976).

75. 15 U.S.C. $\S \S 1011-1015$ (1976).

76. Id. \& 1012(b).

77. Hewlett-Packard, 571 F.2d at 505.

78. $I d$.

79. 442 F. Supp. 695 (N.D. Cal. 1977).

80. Haw. Rev. Stat. $§ \S 393-1$ to 393-51 (1976).
} 
including coverage for alcohol and drug abuse, could have been characterized as a state insurance law saved from preemption, the decision emphasized the "relates to" language of section 514 in finding preeinption. The Hawaii statute was held to be preempted despite the fact that ERISA does not impose any substantive requirements regarding the content or coverage of prepaid health plans. The arguinent of the State of Hawaii that preeinption should be found only when the state atteinpts to regulate areas covered by ERISA was specifically rejected by the court:

Insofar as the Hawaii Act does not regulate matters covered by ERISA (basically reporting, disclosure, funding, vesting, and fiduciary duties) it would not, under this interpretation, be superseded because it does not relate to employee benefit plans in any of the ways that ERISA relates to einployee benefit plans . . . . Under this interpretation, Hawaiian workers would obtain the protection of both the Hawaii Act which regulates benefits, but not administration, and ERISA which regulates administration but not benefits. However wise Congress might have been to take this approach to preemption of state laws regulating einployee benefit plans, Congress clearly rejected it. ${ }^{81}$

Hewlett-Packard and Agsalud can be contrasted with Wadsworth $v$. Whaland. ${ }^{82}$ In Wadsworth, the First Circuit circumscribed the focus of ERISA's preeinption provisions and upheld state primacy in the regulation of insurance under the msurance proviso in section 514(b)(2)(A). Wadsworth involved a New Hampshire statute ${ }^{83}$ that prescribes the content of group health insurance pohicies issued within the state, including pohicies issued to einployee benefit plans, by requiring that issuers of such pohcies provide coverage for the treatment of mental illness and enotional disorders. While admitting that the legislative history of ERISA indicates an intent "to preempt all state laws that relate to enployee benefit plans and not just state laws which purport to regulate an area expressly covered by ERISA," 84 the court held that preemption does not necessarily follow from a finding that a state statute indirectly relates to an employee benefit plan.

When a state statute both regulates insurance law and indirectly

81. Agsalud, 442 F. Supp. at 706-07.

82. 562 F.2d 70 (1st Cir. 1977), cert. denied, 435 U.S. 980 (1978). The Ninth Circuit in Hewlett-Packard directs our attention to Wadsworth with a compare citation, $571 \mathrm{~F} .2 \mathrm{~d}$ at 505 .

83. Each insurer that issues or renews any policy of group or blanket accident or health insurance providing benefits for inedical or hospital expenses, shall provide to each group, or to the portion of each group comprised of certificate holders of such insurance who are residents of this state and whose principal place of employment is in this state, coverage for expenses arising from the treatment of mental illnesses and einotional disorders.

N.H. REv. STAT. ANN. § 415:18-(a)(I) (1976).

84. Wadsworth, 562 F.2d at 77 (emphasis in original). 
relates to an employee benefit plan, the court in Wadsworth found that the conflict must be resolved by application of the "deemer" clause of section 514(b)(2)(B). ${ }^{85}$ The plaintiffs, administrators of various health and welfare plans, contended that the "deemer" clause prohibiting a state from deeming an employee benefit plan to be an imsurance company, denies a state the ability to affect plans indirectly by regulatimg the content of the insurance policies they purchase. The court rejected this construction of the "deeiner" clause because it would "greatly diminish the state's primacy in regulating insurance," 86 an object clearly protected both by section 514(b)(2)(A) of ERISA and by the McCarran-Ferguson Act.

The First Circuit opinion in Wadsworth agreed with the district court's finding in Hewlett-Packard that "the deemer provision prevents a state from subjecting a plan, as a business of insurance, to the state's general insurance laws or enacting special legislation regulating plans as 'a unique variety of insurance." "87 But the Wadsworth court distimguished Hewlett-Packard, stating that "on its face the deeiner provision does not prohibit a state from indirectly affecting plans by regulatimg the contents of group insurance policies purchased by the plans." ${ }^{\text {"88 }}$ In fact, the First Circuit's opinion provides httle guidance im determming when a state's insurance law is a guise to regulate einployee benefit plans and when such a law is a legitimate exercise of the authority reserved to the state to regulate insurance, which indirectly affects an employee benefit plan.

In Hewlett-Packard, the court denied the right of a state to regulate einployee benefit plans througl the device of regulating insurance; in Wadsworth, the court demied federal preemption of a state imsurance law merely because it affects employee benefit plans. In Hewlett-Packard, the court referred to the state action as a "direct" regulation of employee benefit plans; in Wadsworth, the court described the state action as an "indirect" regulation of such plans. If these two cases are to be reconciled, the apparent distinction is in the manner in which the laws "relate to" employee benefit plans: the New Hainpshire law challenged in Wadsworth regulates group health insurance policies and mandates substantive items of coverage, while the California law addressed by the Hewlett-Packard court regulates "health care service plans" and mandates non-substantive aspects of plan administration. The California Act trespasses on ERISA territory, while the New
85. Id.
86. Id.
87. Id.
88. Id. 
Hampshire statute does not. Given ERISA's stated respect for state primacy in the area of imsurance regulation, a direct trespass may be worthy of preemption - at least in the Ninth Circuit-but an indirect, yet substantial, economic burden on plans is not-at least in the First Circuit.

Judge Renfrew's decision in Agsalud may also be reconciled with the First Circuit's holding in Wadsworth under a similar rationale. The Hawaii statute which was preempted in Agsalud apphed to employee benefit plans directly and mandated certain coverage provisions. By comparison, the New Hampshire statute mandated the coverage of all group health insurance pohicies issued within the state, of which pohcies sold to employee benefit plans constituted only one subset or classification. The broader applicability of the New Hampshire statute may have made the First Circuit more reluctant to strike down the state's exercise of traditional authority.

In an opmion which followed the rationale in Wadsworth, a Minnesota federal district court in Insurers' Action Council v. Heaton ${ }^{89}$ refused to find preemption of Minnesota's Comprehensive Health Insurance Act. ${ }^{90}$ The Act requires that every health insurer offer Minnesota residents pohcies including a specified amount of major medical coverage; that employer sponsors of health care plans make available a plan providing the statutorily mandated benefits, regardless of whether such plans are funded through insurance contracts; and that a state Health Association be created to offer policies to individuals otherwise unable to obtain health and medical imsurance. The court cited the insurance proviso in section 514(b)(2)(A), asserting that "the conflict between the challenged state insurance law and ERISA has to be very clear in order to trigger the preemption provision." 91 The court further noted that the ouly substantive provisions of ERISA which relate to health and accident insurance plans, or to welfare plans generally, are reporting and disclosure requirements. These provisions do not purport to regulate "the substance of the insurance plans which employers must offer their einployees." 92 Thus, the substantive provisions of ERISA did not result in sufficient conflict with the substantive requirements of the Minnesota insurance law to warrant preemption.

In light of this minimal interference with an area of traditional state primacy, the court cited section 514(d) of ERISA in support of its conclusion that ERISA "shall not be construed to supersede any law of

\footnotetext{
89. 423 F. Supp. 921 (D. Minn. 1976).

90. 1976 MinN. LAws. Ch. 296.

91. Heaton, 423 F. Supp. at 926.

92. Id.
} 
the United States,"93 including the McCarran-Ferguson Act which "mandates that the business of insurance shall be regulated by the states." The court in Heaton went further than the First Circuit in Wadsworth by upholding the state law in its entirety, including the provision that apphed specifically to employer sponsors of health care plans, regardless of whether such plans are funded through insurance contracts. Insofar as the state law regulates insurance, the Wadsworth rationale and the deemer provision of section 514(b)(2)(B) are forceful arguments in favor of state primacy. But, insofar as the state statute attempts to regulate einployee benefit plans directly, by imposing substantive requirements on plan sponsors, it would appear to be outside the uunbrella of perimssible state action, as evidenced by the language of section 514 .

This line of cases, which attempts to distinguish a state msurance law froin a state law which relates to einployee benefit plans, is troublesome. The courts appear generally to have interpreted a state law to be a non-preempted insurance law so long as it affects einployee benefit plans only indirectly. A state law is presunnably saved from preeinption if it is couched in terms of overall insurance regulation, because einployee welfare benefit plans are only one category-although a fairly large category - of entities affected by a law that regulates, for example, all group health insurance policies issued in the state. Yet the courts have in fact given little guidance in determining when a state law which is merely labeled as an "insurance law" may be a guise to regulate employee benefit plans and when such a law is a legitimate exercise of the state's traditional authority in the area of msurance, an area which Congress specifically chose to reserve to the states.

In the absence of congressional clarification, the states appear to be left with the authority to regulate indirectly the substantive coverage of employee welfare benefit plans. If Congress imtended areas such as the substantive coverage of welfare plans to be reserved to the states through the insurance proviso, then the outcoine of these judicial decisions is not disturbing. It should be noted, however, that this result seriously undermines ERISA's preeinption provisions. The ability of each state to mandate the substantive coverage of welfare plans, through the regulation either of group insurance policies issued within the state or of the benefits provided to policy holders within the state, would impair the congressional goal of uniformity of regulation of employee benefit plans.

If Congress intended to promote the uniform regulation of both

93. Id.

94. $I d$. 
welfare and pension plans through the section 514 preemption language, the insurance proviso provides insufficient guidance. Because the overlap and interface between insurance and employee benefit plans-particularly employee welfare benefit plans-are so great, Congress should reexamine its goals with respect to state insurance regulation. If the congressional policy underlying the McCarran-Ferguson Act is found to be dominant, then a certam degree of uniformity in the regulation of einployee welfare benefit plans must be lost. If, however, federal law alone must regulate employee welfare benefit plans, a further statement of congressional intent is necessary.

The label placed on a state law, whether it be insurance regulation, fair employment law or disability insurance regulation, should not be the determinative factor in balancing competing state and federal issues under the preemption doctrine. Congress should clarify its intent with respect to these two areas affecting welfare plans so that the courts can properly balance the state and federal interests without being influenced by a superficial label. ${ }^{95}$

\section{B. Preemption of State Law "Insofar as it Relate[s] to" Retirement Plans: The Federal Interest in the Integrity of the Retirement Fund versus the State Interest in the Welfare of its Citizenry.}

1. The Uniqueness of Retirement Benefits: The Pre-ERISA Federal Cases. Both legislation and judicial rulings have traditionally treated retirement benefits differently from other forms of einployee benefits. More than health, life insurance or other types of benefits, retirement or pension benefits have been thought essential to einployees' financial security. Federal courts have often been willing to find preeinption of state law where to do so was to proinote the federal interest of guaranteeing federally provided retirement funds against opposing claims under state law.

Philpott v. Essex County Welfare Board ${ }^{96}$ involved a potential con-

95. The ERISA Improvements Act of 1979, S. 209, 96th Cong., 1st Sess., represents an attempt by Congress to clarify its intent with regard to the meaning of the insurance proviso of $\S 514(\mathrm{~b})(2)(\mathrm{B})$. Section 155 of the bill would amend $\S 514$ of ERISA to provide that a state insurance law which requires that a particular benefit be provided by an insurer selling policies to employee benefit plans covered by ERISA is preeinpted and not saved under $\S 514(b)(2)(B)$. However, a state law which directly or indirectly requires that employers provide certain health care benefits or services to their employees would not be preempted, nor would a state law which regulates the administration of arrangements under which health care benefits or services are provided. Thus, state laws which impose substantive coverage requireinents for health care plans or regulate the administration of an einployer's health care program or arrangement would not be preempted. A variety of differing state laws could, under this provision, be applicable to a multistate plan.

96. 409 U.S. 413 (1973). 
flict between the Social Security Act and a New Jersey law which provided for the reimbursement of welfare funds. The Supreme Court held that the fixed prohibition in the Social Security Act against the assignment or alienation of benefits ${ }^{97}$ preempted the state law. The Court prevented the welfare board froin enforcing a reimburseinent agreement signed by the welfare recipient and thus refused to permit the welfare board to reach the bank account in which the recipient had deposited disability payments received under the Social Security Act.

Federal courts have also protected the integrity of federally provided retirennent benefits against conflicting claims of third parties based on state community property laws. For example, in Wissner $v$. Wissner $^{98}$ the Supreme Court held that the provision in the National Service Life Insurance Act, exempting payinents from attachment or levy, preempted the application of state community property statutes. The Court found that the law's exemption of proceeds from alienation or assignment was "in flat conflict with" and therefore superseded any California community property law which would divide the proceeds either before or after paynent. The Court cited the need to protect the integrity of the fund in support of its finding of federal preenption. ${ }^{99}$ In balancing the federal and state interests, the Court noted that although "venerable and worthy," community property principles do not "justify an exception to the congressional language." 100

Similarly, in Free v. Bland ${ }^{101}$ the Supreme Court held that an application of Texas community property principles must be superseded by Treasury Department regulations which created a right of survivorship in the co-owners of United States Savings Bonds. The Court rejected a claim of the son of the deceased spouse, holding that the state's community property law could not be applied so as to defeat the federally granted sole ownership rights of the surviving spouse. In balancing the state and federal interests the Court took a strong stand on the side of federal preeinption. ${ }^{102}$

ERISA includes within its detailed scheme of pension plan regulation a number of specific statutory provisions designed to proinote the financial soundness of employee benefit plans. One such provision is the prohibition of the assignment or alienation of plan benefits. Section 206(d) of ERISA requires that "[e]ach pension plan shall provide that benefits provided under the plan may not be assigned or alien-

\footnotetext{
97. 42 U.S.C. $\$ 407$ (1976).

98. 338 U.S. 655 (1950).

99. Id. at 660 .

100. Id.

101. 369 U.S. 663 (1962).

102. Id. at 666 .
} 
ated."103 This provision, which is also made applicable to all qualified plans under section $401(\mathrm{a})(13)$ of the Code, ${ }^{104}$ restates a pre-ERISA Code provision which similarly prohibited the assignment or alienation of retirement benefits under private tax-qualified pension plans. ${ }^{105}$

This federal interest in protectimg the retirement income of retirees and the overall integrity of pension plan benefits has come into conflict with the states' interest in their doinestic relations law. Most of the case law relatimg to pension plans and preemption of state law by ERISA has involved the conflict between these two interests.

2. The California Challenge: Community Property Principles for Allocating Spousal Rights. Even before the California Supreme Court's decision in In re Marriage of Brown, ${ }^{106}$ holding that non-vested as well as vested pension benefits are community property subject to division in a marriage dissolution proceeding, the conflict between state cominunity property principles and a federal prohibition of the assignment of retireinent benefits had become a central issue in California domestic relations cases.

California courts have been generally unwilling to follow the Supreine Court's holdimgs in Wissner and Free. In In re Marriage of Fithian ${ }^{107}$ the California Suprene Court distinguished Wissner and held that Arnied Forces retirement pay was subject to division under community property principles. The court stated that Wissner had "no controlling impact on the case at bar except to mandate us to examme the legislative goals behind the military retirement pay system." $108 \mathrm{Be}-$ cause the court refused to find California community property law "irreconcilable" or "incompatible" 109 with the military retirement system, it held that cliaracterization of such retirement benefits as community property would not conflict with the beneficiary designation provision of the federal law. ${ }^{110}$

The California Supreme Court in In re Marriage of Hisquierdo ${ }^{111}$

103. 29 U.S.C. $\S 1056(d)(1)(1976)$.

104. Section 401(a)(13) of the Code similarly provides in part that "[a] trust shall not constitute a qualified trust under this section unless the plan of which such trust is a part provides that benefits provided under the plan may not be assigned or alienated." I.R.C. \& 401(a)(13).

105. See the regulations at 26 C.F.R. $\S 1.401-2$ (1978), which prohibit the diversion of plan funds for any purpose other than the exclusive benefit of einployees and their beneficiaries. The IRS based its pre-ERISA prohibition against the assignment or alienation of plan benefits on these provisions.

106. 15 Cal. 3d 838, 544 P.2d 561, 126 Cal. Rptr. 633 (1976).

107. 10 Cal. 3d 592, 517 P.2d 449, 111 Cal. Rptr. 369 (1974).

108. Id. at 598, 517 P.2d at 452,111 Cal. Rptr. at 372.

109. Id. at 601,517 P.2d at 454,111 Cal. Rptr. at 374.

110. Id. at 601,517 P.2d at 454-55, 111 Cal. Rptr. at 374-75.

1I1. 19 Cal. 3d 613, 566 P.2d 224, 139 Cal. Rptr. 590 (1977), rev'd sub nom. Hisquierdo v. Hisquierdo, 99 S. Ct. 802 (1979). The California Supreine Court's decision was, however, subse- 
held that a prohibition of assignment or alienation of benefits payable under the Railroad Retirement Act ${ }^{112}$ did not preclude a state divorce court from awarding such benefits in a dissolution decree according to community property principles. The court characterized the WissnerFithian dichotomy by saying:

[W] henever there is a conflict between a federal statute affording annuity or insurance benefits and state cominunity property laws the federal statute nuust prevail. However, if the intent of Congress in creating the federal right is not violated by application of California's community property laws, then the status of such rights is governed by California law. ${ }^{113}$

The court found that the federal prohibition of the assignment of railroad retirement benefits was not intended to apply to the claims of the spouse, and therefore did not conflict with community property principles. "[T]he essential purpose of . . . [the prohibition agamst the anticipation of payment was] to bar creditors of the beneficiary from reaching annuity payments, rather than to prevent a spouse from vindicating her ownership interest in the pension." 114

It should be noted that neither Fithian ${ }^{115}$ nor Hisquierdo ${ }^{116}$ involved a direct award of retirement benefits fronu a plan to a divorcing spouse. These decisions required only that retirement benefits be included in the divisible community property. Neither court ordered a directing payment from the retirement plan; rather both ordered the employee to make payinents pursuant to the dissolution decree, after receiving the benefits.

A concept frequently cited in Califorina marriage dissolution actions involving retirement benefits protected by a prohibition of anticipation is the notion that commumity property principles require inerely

quently reversed by the Supreme Court, which held that benefits payable under the Railroad Retirement Act could not be divided under community property law. The Court held that the provision of the Railroad Retirement Act which prohibited the assignment or alienation of benefits barred the community property claims of a divorcing spouse. 45 U.S.C. $\$ 23 \mathrm{Im}$ (1976). It is important to note that the Court found that the prohibition against the assignment or alienation of benefits contamed in the Railroad Retirement Act did not apply to any alimony or child support claim, since Congress, in amending $\S 459$ of the Social Security Act, intended to make an exception to $\$ 23 \mathrm{ln}$ and similar provisions in all other federal benefit plans. $99 \mathrm{~S}$. Ct. at 811 . See the discussion of $\$ 459$ of the Social Security Act as amended in note 172 infra. See also Hipsley v. Hipsley, 161 N.J. Super. 119, 390 A.2d 1220 (Ch. Div. 1978), in which the New Jersey Superior Court, Ocean County, Chancery Division held that pension benefits under the Railroad Retirement Act were not subjeet to equitable division.

112. 45 U.S.C. \$\$ 231-231t (Supp. V 1975).

113. 19 Cal. 3d at 616, 566 P.2d at 225,139 Cal. Rptr. at 591.

114. Id. at 617,566 P.2d at 226, 139 Cal. Rptr. at 592.

115. 10 Cal. 3d at 604, 517 P.2d at 457, 111 Cal. Rptr. at 377.

116. 19 Cal. 3d at 617-19, 566 P.2d at 227-28, 139 Cal. Rptr. at 593-94. 
an allocation of property rights, not a prohibited assignment. ${ }^{17}$ The non-einployee spouse in a community property state may be viewed as owning a share of any retirement benefits at the time such benefits are earned or accrued. A division of retirement benefits pursuant to a divorce decree would, therefore, be a mere allocation of pre-existing property rights, not an assignment of rights prohibited under section 206(d) of ERISA.

Even if the section 206(d) probibition of the assignment or alienation of benefits does not apply to the imterest of a divorcing spouse in a community property state, certainly an order directing a retirement plan to pay benefits to a non-employee spouse would "relate to" an employee benefit plan as contemplated by section $514 .{ }^{118}$ However, the state law would be preempted only "insofar as" it relates to the retireinent plan. Thus, preeinption would not reach the state statute; rather, it would be limited to an application of state community property principles requiring direct payment from a retirement plan to satisfy the property interests of a divorcing spouse.

Most courts in community property states have failed to recognize the crucial limitation on ERISA preemption created by this "imsofar as" language. ${ }^{119}$ The California courts have viewed efforts by a plan to

117. See, e.g., Phillipson v. Board of Administration, 3 Cal. 3d 32, 473 P.2d 765, 89 Cal. Rptr. 61 (1970). Phillipson is often cited in community property states for the proposition that a division of community property interests constitutes no more than an allocation of pre-existing benefit rights. In Phillipson the Supreme Court of California denied the application of a state statute prohibiting assignnent of state enuployees' pension benefits and permitted a division of a state employee's retirement benefit pursuant to a marriage dissolution decree. The court held that a divorcing spouse "claims not as a creditor, but as an owner with a 'present, existing, and equal interest.' [Citation ounitted]. The recognition of an ownership claim cannot be described as the levy of execution, garnishment, attachment or assignment of property." 3 Cal. 3d at 44, 473 P.2d at 772, 89 Cal. Rptr. at 68 . While Phillipson represents yet another case in which a prohibition of the assignment of benefits was held not to prevail against the claim of a divorcing spouse, it should be noted that this case did not involve a claim of preeinption under a federal statute. Moreover, while the court in Phillipson permits an award of benefits to a divorcing spouse that would take into account retirement benefits, the court suggests that such an award need not be enforced directly against a retirenient plan: "[A]ll parties agree, and we concur, that if the community musters sufficient assets to do so, the preferable mode of division would be to award the pension rights to the einployee and property of equal value to the spouse." 3 Cal. $3 \mathrm{~d}$ at $46,473 \mathrm{P} .2 \mathrm{~d}$ at 774,89 Cal. Rptr. at 70 .

118. A court order requiring a direct payment of benefits from a plan to a non-employee spouse "relates to" a plan within the meaning of $\$ 514$ by prescribing the naimer and method in which benefits are paid under the plan, subjects clearly regulated by the provisions of ERISA. For example, ERISA frequently requires that benefits be made available im the form of a joint and survivor annuity, that benefit payments begin no later than 60 days following the close of the plan year in which an event such as retirement or termination of service occurs, and that lump sum distributions may be made either voluntarily or involuntarily upon an einployee's termination of employnent only if certaim conditions are net.

119. Courts in non-community property states lrave also failed to recognize the importance of the "insofar as" language of $\S 514$. See, e.g., General Motors Corp. v. Townsend, [1978] 177 
resist a direct order of payment to a non-employee spouse as an attack on basic community property principles that, if preempted, would leave a void ni state domestic relations laws. So, for example, a California state court in In re Marriage of Sommers ${ }^{120}$ permitted the joinder of a pension plan in a divorce action, stating that "[d]eferred compensation, accrued pensions, annuities to take place in the future, and social security, veterans' and insurance benefits are well recognized property rights and are properly the concern of courts upon the severance of the marital relationship." 121 In addition, in both Pardee v. Operating Engineers Pension Trust 122 and Southern California IBEW-NECA Pension Plan v. Superior Court, ${ }^{123}$ the Federal District Court for the Central District of California refused to preempt California community property law, noting its unwillingness to involve federal courts in traditional matters of state doniestic relations. ${ }^{124}$ Citing Pardee, the court in Southern California stated that "if it were necessary to reach the merits, this court would hold that the state court correctly determined that [ERISA] was not intended to preempt or interfere with community property laws." 125

Another example of a refusal to apply section 514's "imsofar as" language to distimguish between preemption of state community property laws and preemption of the apphication of such laws is Judge Renfrew's decision in Stone $v$. Stone. ${ }^{126}$ In that case a non-employee spouse sought to enforce a division of marital property which had been previously made pursuant to a divorce decree issued by a California superior court. The inarital dissolution decree which had divided the couple's marital property under California community property law awarded the wife a forty-percent niterest in the retirement benefits payable each inonth to her husband under the pension plan mamtamed by

PeNs. ReP. (BNA) D-1 (E.D. Mich. 1976), in which the court held that a Michigan statute that had been interpreted as permitting assignments and attachments of pension and retirement benefits conflicted with and was superseded by ERISA $\S 206$ (d) and I.R.C. $\S 401$ (a)(13). The court went on, however, to deny that ERISA $\S 514$ compelled a finding of preemption because, in the court's view, the relationship between the Michigan law and retirement plans "is too indirect and tangential." [1978] 177 PENS. REP. at D-2. The court feared that a findimg of preemption would result in the overruling of "all state law on all subjects that might have some peripheral connection with employee benefit plans." Id. The "insofar as" language in $\$ 514$ could, however, be interpreted as requiring prcemption only of any apphication of the state law which requires a direct payment of bencfits from a retirement plan and thus relates to and affects employee benefit plans.

120. 53 Cal. App. 3d 509, 126 Cal. Rptr. 220 (1975).

121. Id. at $515,126 \mathrm{Cal}$. Rptr. at 224.

122. 408 F. Supp. 666 (C.D. Cal. 1976).

123. [1976] 105 Pens. REP. (BNA) D-18 (C.D. Cal. 1976).

124. See, e.g., Pardee, 408 F. Supp. at 669.

125. [1976] 105 PENS. REP. (BNA) D-18 (dicta).

126. 450 F. Supp. 919 (N.D. Cal. 1978). 
the Pacific District of the Seafarers International Union. ${ }^{127}$ After almost three years of noncompliance with the divorce decree, the nonparticipant former spouse sought to enforce her judgment against the retirement plan, seeking a court order requiring the plan to pay her share directly to her each month. Defendants renioved the action to federal court and Judge Renfrew found federal jurisdiction under section 502(a)(1) of ERISA, ${ }^{128}$ which permits a plan participant or beneficiary "to recover benefits . . . to enforce his rights . . . or to clarify his rights to future benefits under the terms of the plan." Judge Renfrew stressed that once pension benefits had been awarded under a community property allocation pursuant to a divorce decree, a former spouse would have a very difficult time enforcing these property rights without a finding of jurisdiction to sue the plan directly under section 502 of ERISA:

To deny a nonemployee spouse awarded benefits in a divorce action the right to sue under $\$ 502(a)(1)(B)$ leaves her dependent on the willingness of her spouse to sue the plan or its trustees on her behalf, which the spouse has hittle or no incentive to do. ${ }^{129}$

After finding federal jurisdiction to enforce the divorced spouse's claim against the pension plan, the court then examined the issue of federal preemption in the context of both section 206(d) and section 514 of ERISA. With respect to section 206(d), the court found that that provision should not apply to a transfer of pension benefits pursuant to community property rights and that "[ $[$ t] he payment of benefits to a nonemployee spouse in satisfaction of her community property claim does not conflict with the purposes of $\S 206(d)(1)$. Meinbers of the families of einployees are included in the class which ERISA protects. ${ }^{130}$

With respect to section 514, the court assumed that a finding of preeniption would result in a coniplete invalidation of the state's coinmunity property law with respect to employee benefit plans. It was with this erroneous belief in mind that Judge Renfrew declared that preemption would "involve a inuch more radical disturbance of "the federal-state balance" " than could have been intended by Congress. ${ }^{131}$

Pardee, Southern California and Stone balanced the federal interests served by ERISA's prohibition of the assignment or alienation of

127. Id. at 920 .

128. 29 U.S.C. $\& 1132(a)(1)$ (1976).

129. $450 \mathrm{~F}$. Supp. at 922 . But see National Bank of N. America v. Local 533 Pension Fund of Int'l Bhd. of Teamsters, 463 F. Supp. 636 (E.D.N.Y. 1978) (federal courts restricted standing to sue under ERISA \& 502(a)(1)(B) to employee participants and designated beneficiaries); Kerbow v. Kerbow, 421 F. Supp. 1253 (N.D. Tex. 1976).

130. $450 \mathrm{~F}$. Supp. at 926.

131. Id. at 932. 
retirement benefits against the state's interest in preserving its exclusive authority over domestic relations matters. When these two intcrests are counterposed, the state's argument is appealing. However, as a result of section 514's "insofar as" language, it is not the state's broad interest in its domestic relations law, but rather a much narrower state interest in a particular application of that law, which is to be balanced against the federal interests im uniformity of regulation and integrity of plan assets.

In Francis v. United Technologies Corp. ${ }^{132}$ the defendants successfully urged a very narrow preemption of a single application of California's community property principles. In that case, a divorcing noneinployee spouse brought an action against the employer maintaining the pension plan in which her husband was a participant, the plan's trustee and the plan's insurer/administrator. She sought a declaratory judgment of her community property interests in the pension plan and the creation of a constructive trust on her behalf. Judge Poole, writing for the Federal District Court for the Northern District of California, cited Wissner with approval and granted defendants' motion for sun1mary judgment. The court held that "ERISA has preempted the operation of so nuch of California's community property laws as purport to give a non-employee spouse an interest in the plan benefits," 133 and that the plaimtiff had no cause of action under section 502 of ERISA. ${ }^{134}$

\section{The New York Challenge: The Right to Support Becomes the} Issue. Judge Renfrew's statement in Stone that section 206(d) of ERISA should not be interpreted to bar the claims of an employee participant's spouse or other dependents because "[in]embers of the families of einployees are included in the class which ERISA protects," 135 reflects a theme frequently repeated in New York and several other common law jurisdictions. In these jurisdictions it is the state's interest in the familial support obligation traditionally borne by the family's major wage earner, rather than the state interest in the division of marital property, which is raised as a response to federal preemption.

Prior to ERISA, both state and federal courts had been reluctant to hold that a federal provision exempting retirement benefits from assignment or alienation could prevail against the alimony or child sup-

132. 458 F. Supp. 84 (N.D. Cal. 1978).

133. Id. at 86 .

134. 29 U.S.C. $§ 1132$ (1976). Federal jurisdiction in Francis was founded on diversity of citizenship. Judge Poole specifically rcjected the view that the plaintiff divorcing spouse could be viewed as a "participant" or "beneficiary" entitled to bring an action in federal court under $§ 502$ of ERISA. Accord, Kerbow v. Kerbow, 421 F. Supp. 1253 (N.D. Tex. 1976).

135. 450 F. Supp. at 926. 
port claims of the employee's dependents. As Judge Rutledge noted in Schlaefer v. Schlaefer: ${ }^{136}$

[T] he usual purpose of exemptions [from the assignment or ahenation of pension benefits] is to relieve the person exempted from the pressure of claims hostile to his dependents' essential needs as well as his own personal ones, not to reheve him of familial obligations and destroy what may be the family's last and only security, short of public relief. ${ }^{137}$

In Brown v. Brown, ${ }^{138}$ an Ohio state court refused to dissolve a previously issued order against the husband of a divorcing spouse restraining the disposition of the proceeds of a social security check pending a petition for divorce and alimony. The court held that a wife's alimony claim was distimguishable from that of a creditor and was, therefore, unaffected by the provision of the Social Security Act ${ }^{139}$ which exempts Social Security benefits from assignment or alienation. ${ }^{140}$ The court found the purpose of that prohibition on assignment to be the protection of both the recipient of Social Security benefits and those dependent on him. ${ }^{141}$

Similarly, both state and federal courts in common law property states have distimguished the claims of wives and other dependents froin those of general creditors within the context of ERISA's section 206(d) prohibition against the assignment or ahenation of benefits. In Cody v. Riecker, ${ }^{142}$ the Federal District Court for the Eastern District of New York held that section 206(d) and the provision of a pension plan prohibiting the assignment or alienation of benefits pursuant to section 206(d) could not bar an execution upon pension benefits to enforce a support obligation. In that case the Family Court of the State of New York had issued a judgment for arrears on a retired einployee spouse's obligation of support; the judgment was enforced by levying on the employee spouse's pension plan. The plaintiff trustees of the plan brought an action to enjoin the levy, based on section 206(d) of ERISA. The court held that section 206(d) could not be interpreted so as to bar the enforcement of a liusband's support obligation to his wife, and cited Stone for the proposition that Congress could not have in-

136. 112 F.2d 177 (D.C. Cir. 1940).

137. Id. at 185.

138. 32 Ohio App. 2d 139, 288 N.E.2d 852 (1972).

139. 42 U.S.C. $\$ \S 301-432$ (1976).

140. Id. $\$ 407$.

141. "The intent behind the exemption in the Social Security Act is to protect the appellant and those dependent on him from the claim of creditors. Appellee's claim for alimony, different from a claim of a creditor, is unaffected by the exemption set forth in section 407." 32 Ohio App. $2 \mathrm{~d}$ at 141,288 N.E.2d at $853-854$.

142. 454 F. Supp. 22 (E.D.N.Y. 1978), affd, [1979] 230 PENS. ReP. (BNA) D-22 (2d Cir. 1979). 
tended such a radical encroachment on traditional state interests: "[A] Congressional intent to pre-einpt state law in such a matter is not hightly to be presumed in the absence of an unambiguous declaration of intent." 143 Lacking clear legislative history in ERISA regarding preemption of the state-created support obligation, the court in Cody chose to follow the line of cases ${ }^{144}$ which has traditionally "afforded deference" to this state interest. ${ }^{145}$

In Cartledge v. Miller, ${ }^{146}$ the Federal District Court for the Eastern District of New York adopted the position urged by the Justice Department in its amicus brief on behalf of the Secretaries of Labor and the Treasury. The government approach would create an implied exception froin the prohibitions of section 206(d) in the case of court-issued support orders. In Cartledge, the County of Rockland, on behalf of the Rockland County Department of Social Services, had obtained a court order garnishing the pension benefits of a retired participant to fulfill support obligations owed to his wife and to pay arrearages which had been assigned to the county by the participant's wife in return for public welfare received by her. ${ }^{147}$ The pension committee that admmistered the participant's plan sought to enjoin the enforceinent of the state court order as an invahd assignment or alienation of pension benefits.

Judge Weinfeld refused to infer federal preenption from section 206(d) in the absence of clear legislative history providing guidance as to the scope of ERISA's prohibition of assignments and prescribing preemption of state support laws. ${ }^{148}$ Regarding preeinption generally, the court found the state's interest in enforcing familial maintenance and support obligations to be weightier than the "generalized proscriptions" 149 of ERISA's section 514. In fact, the court in Cartledge argued

143. 454 F. Supp. at 24.

144. See, e.g., Schlaefer v. Schlaefer, 112 F.2d 177 (D.C. Cir. 1940); In re Bagnalli Guardianship, 238 Iowa 905, 29 N.W.2d 597 (1947); Brown v. Brown, 32 Ohio App. 3d 139, 288 N.E.2d 852 (1972); Huskey v. Batts, 530 P.2d 1375 (Okla. Ct. App. 1974); Dillard v. Dillard, 341 S.W.2d 668 (Tex. Civ. App. 1960).

145. 454 F. Supp. at 24.

146. 457 F. Supp. 1146 (S.D.N.Y. 1978).

147. The plan participant had failed to meet his support obligation to his wife and children for almost twenty ycars prior to his retirement in 1977, at which time his arrearages under prior orders were substantial. In 1977, a New York Family Court issued a payroll deduction order for amounts to be withheld froin the participant's pension benefit to satisfy the amounts owed to the County Department of Social Services. Id. at 1150.

148. "As a fundamental principle of statutory interpretation, courts have presumed that the basic police powers of the States, particularly the regulation of domestic relations, are not superceded [sic] by federal legislation unless that was the clear and manifest purpose of Congress." Id. at 1154 (footnote omitted).

149. Id. 
that "the goals underlying ERISA support the reasoning of this common law presumption" 150 im favor of state enforcement of familial obhgations. Citing from the legislative history of ERISA, the court noted Congress' concern for the
"continued well-being and security of millions of employees and their dependents [who] are directly affected by these plans. . . ." Rather than intending to undermine the family law rights of dependent spouses and children, the legislature was concerned that "employees and their beneficiaries"-the entire family-be protected by ER- ISA. ${ }^{151}$

Thus, the court refused to adopt a hiteral reading of section 206(d) and section 514 of ERISA, which would preempt state laws enforcing familial support obligations. The traditional imterest of the state in domestic relations matters so fundamental as the security of family dependents was held to outweigh generalized federal imterests im the absence of very specific congressional language mandatimg a contrary result. ${ }^{152}$

Other decisions in non-community property states have similarly upheld the obhigation of a bread winner to support his dependents. In Cogollos v. Cogollos ${ }^{153}$ and Wanamaker v. Wanamaker, ${ }^{154}$ two New York state courts held that ERISA's section 206(d) could not insulate an employee spouse from vahid support claims which represent a traditional and longstanding interest of the state. ${ }^{155}$ In Wanamaker the court found that the "spouse is not a creditor . . . . Her position is that of one who is seeking her natural and statutory rights as a former wife." 156 Like the court in Cartledge, the Wanamaker court pointed to the Congressional Findings and Declaration of Policy in section 1 of ERISA $^{157}$ as evidence that ERISA itself recognizes the right to support

150. Id. at 1156.

151. Id. (footnote omitted) (emphasis supplied by court).

152. See also AT\&T v. Merry, 26 F.R. Serv. 2d 877 (2d Cir. 1979), in which the Second Circuit cited Cartledge and Cody in finding an implied exceptiou to ERISA's prohibition of assignment or alienation in the case of court-ordered family support obligations.

153. 93 Misc. 2d 406, 402 N.Y.S.2d 929 (Sup. Ct. 1978).

154. 93 Misc. 2d 784, 401 N.Y.S.2d 702 (Fam. Ct. 1978).

155. See also the decision of the Family Court of the State of New York in In re M.H. v. J.H., 93 Misc. 2d 1016, 403 N.Y.S.2d 411 (Fam. Ct. 1978), which held that a child support order requiring a payroll deduction from the inonthly pension benefits of a retiree was not superseded by ERISA. The court pointed out that the pension plan's prohibition against the assignment or alienation of benefits which was required under $\$ 206$ (d) of ERISA was intended to protect the family from outsiders rather than to help one meinber of the family avoid his support obligations.

156. 93 Misc. $2 d$ at 787,401 N.Y.S.2d at 705.

157. The Congressional Findings and Declaration of Pohcy, ERISA § 1(a) (codified at 29 U.S.C. $\$ 1001$ (a) (1976)), states in part

that the continued well-being and security of millions of employees and their dependents are directly affected by these plans. . . [and that] it is desirable in the interests of employ. 
and the necessity to promote the contimued well-being of both employees and their dependents. ${ }^{158}$ Similarly, in Cogollos the court rejected a federal preemption argument urging that section 206(d) prohibits a direct order deducting alimony support payments from the inonthly pension benefits payable to a divorced einployee. "The Court does not believe Congress intended to create a privileged sanctuary, behind which a delinquent husband or father can thumb his nose at concededly valid and outstanding support orders."159

4. The Problem for Plan Administrators and a Possible Resolution. Against this backdrop of recent court decisions concerning the interaction of state domestic relations law and ERISA, the dilemma of the plan administrator faced with a court order awarding benefits from a retirement plan to a non-employee spouse must be exammed. Most of the probleins relate to (1) possible tax disqualification of the plan for failure to comply with the prohibition of assignment in section 401 of the Internal Revenue Code; (2) potential fiduciary liability for failure to comply with the "exclusive purpose" requirement of section 404 of ERISA or with the terms of the plan; and (3) a nuinber of technical issues which could arise from the conflicting requirements of a court award and specific provisions of both the Code and ERISA.

As noted above, ${ }^{160}$ section 206(d) of ERISA and Code section 401(a)(13) require that a retirement plan include a provision prohibiting the assignment or alienation of plan benefits. If a payment to a non-employee spouse, pursuant to court order, is viewed as a prohibited assignment or ahenation of benefits, a plan administrator's failure to comply with this plan provision could result in the disqualification of the plan. In Cartledge, the Internal Revenue Service, through the amicus brief filed by the Department of Justice on behalf of the Secretaries of Labor and the Treasury, concluded that Congress intended to exeinpt family support decrees from the general prohibition of assignment and alienation in section 401(a)(13) of the Code. ${ }^{161}$

ees and their beneficiaries . . . that disclosure be made and safeguards be provided with respect to the establishment, operation, and administration of such plans.

(Emphasis added.)

158. 93 Misc. $2 d$ at 787, 401 N.Y.S.2d at 704-05.

159. 93 Misc. 2d at 408,402 N.Y.S.2d at 930 .

160. See notes 103-05 supra and accompanying text.

161. $457 \mathrm{~F}$. Supp. at 1156. The IRS took the same position in an amicus brief filed by the Justice Department on behalf of both the Secretaries of Labor and the Treasury im AT\&T v. Merry, No. Civ. B-78-161 (D. Conn. Oct. 2, 1978), affd, 26 F.R. Serv. 2d 877 (2d Cir. 1979) (discussed supra, note 152).

The Department of Labor, with the acquiescence of the IRS, has taken the concept of an implied exception to § 206(d) of ERISA one step further in its amicus brief filed in Stone v. Stone, 450 F. Supp. 919 (N.D. Cal. 1978). In that brief the Department took the somewhat inconsistent 
In contrast to the Service's position in Cartledge, Merry and Stone, regulations under section 401(a)(13) of the Code are phrased very broadly so as to prohibit "[a]ny direct or indirect arrangeinent (whether revocable or irrevocable) whereby a party acquires froin a participant or beneficiary a right or interest enforceable against the plan in, or to, all or any part of a plan benefit payinent which is, or nay become, payable to the participant or beneficiary." 162 At the present time, this apparent conflict between the explicit language of the IRS regulations and the position taken by the IRS in amicus briefs has not been resolved. ${ }^{163}$ Thus, there is still considerable uncertainty regarding the continued tax qualification of a plan acquiescing to a garnishment by a divorcing spouse.

A plan administrator's failure to comply with a plan provision prohibiting the assignment or alienation of benefits could also result in a breach of the fiduciary responsibility requirements of section 404 of ERISA. ${ }^{164}$ That provision requires, annong other things, that a plan fudiciary such as a trustee or administrator "discharge his duties with respect to a plan ... in accordance with the documents and instruments governing the plan insofar as such documents and imstruments are consistent with the provisions of this Subchapter." 165 Thus, a court order requiring a plan administrator or trustee to pay benefits directly to a non-einployee spouse could force the administrator to choose between compliance with the plan provisions, as required by ERISA, and

position that $\S 514$ of ERISA should be read on its face as preempting the application of community property principles to the benefits payable under an employee benefit plan, while at the same time urging an implied exception to the 206(d) anti-assignment provision of ERISA in the case of a court decree attaching benefits of a participant in pay status to satisfy a claim under state community property law. In footnote 16 of the brief, the Department stated that the Department of the Treasury subscribed to that portion of the brief which deals with the implied exception to ERISA § 206(d) and I.R.C. \$ 401(a)(13).

162. Treas. Reg. $\$ 1.401(a)-13$ (c)(1)(ii) (1979).

163. Moreover, it should be 11oted that the national office's position with respect to an implied exception to the I.R.C. $\$ 401$ (a)(13) prohibition against assignment or alienation may not necessarily be followed by each of the IRS district offices, which have original jurisdiction over matters involving issues of qualification under I.R.C. $\$ 40 I$ (a). In a letter to Robert Sone of IBM, dated June 1, 1976, the IRS national office noted that the district offices have original jurisdiction over questions of plan qualification and further noted a plan's best remedy against a potential garnishment of retirement benefits may be found under ERISA $\S 514$. However, in a subsequent letter, dated September 8, 1978, to John Whittlesey on behalf of Union Carbide Corporation, the IRS national office stated that an implied exception to I.R.C. $\S 401(a)(13)$ and the regulations thereunder has been found im the case of enforcement of family support decrees. This letter poimts out that although neither ERISA nor its legislative history makes any distimction between a garnishment proceedimg to satisfy the claim of an ordinary creditor and a proceeding to satisfy a family support order, "Congress intended an implied exception for family support orders in a case of a pensioner whose right to receive benefits is vested and who is actually im pay status."

164. 29 U.S.C. $\$ 1104$ (1976).

165. Id. § 1104(a)(1)(D). 
compliance with the court order, whicl may be backed by the contempt authority of the court.

Also among the fiduciary obligations imposed by section 404 is the "exclusive purpose" requirement, which provides that "a fiduciary shall discliarge his duties with respect to a plan . . . (A) for the exclusive purpose of: (i) providing benefits to participants and their beneficiaries; and (ii) defraying reasonable expenses of administering the plan." 166 The participant employee spouse could allege that any reduction in his benefits under the plan due to compliance with a court order resulted from a violation of the fiduciary's sole obligation to plan participants and beneficiaries.

Another question that will face a plan administrator who has received a court order requiring the payment of benefits is the extent to whicl a domestic relations court may award relief inconsistent with the terms of the plan or of ERISA. As is true with the possibility of plan disqualification, the administrator is put between the rock of fiduciary breach and the hard place of noncomphance with a court order. Thus, for example, what should a fiduciary do if a court: (1) awards more than the amount payable to the participant under tlie plan, e.g., the award assumes that the participant will receive a single life annuity and, in fact, the participant remarries and receives a reduced periodic payment by virtue of the plan's joint and survivor provisions; (2) awards a benefit payable in a form which is not an optional forin of payinent under the plan, e.g., a lump sum when the plan provides only for an annuity; (3) awards a benefit to be paid immediately when the plan provides that benefits will be paid only upon a participant's retirement or termination of einployment; or (4) awards the right to exercise plan options even though the plan provides that only participants may exercise such options?

ERISA in section $205^{167}$ and the Code in section 401(a)(11) require that any plan offering a benefit in the form of an annuity must provide a "qualified joint and survivor annuity." A "qualified joint and survivor" annuity is defined as

an annuity for the life of the participant with a survivor annuity for his spouse which is not less than one-half of . . the amount of the annuity payable during the joint lives of the participant and his spouse and whiclt is the actuarial equivalent of a single life annuity for the life of the participant. ${ }^{168}$

In the case of a participant, a portion of whose retirement annuity has

166. Id. \& I104(a)(1).

167. Id. \$ 1055 .

168. Id. § 1055(g)(3); I.R.C. § 401(a)(11)(G)(iii). 
been attached by a domestic relations decree, and who has simce remarried, the plan may be put in the impossible position of complying with both the joint and survivor requirements of ERISA and the domestic relations judginent.

Some possible conflicts between a court award of benefits to a noneinployee spouse and the technical requirements of ERISA and the Code inay vary depending on whether the plan is a defined benefit or a defined contribution plan. ${ }^{169}$ Under a defined benefit plan, a grant of rights to a non-einployee spouse, which is not subject to any forfeiture provisions that the plan may have, could upset the plan's actuarial assumptions that assume certain rates of forfeiture. ${ }^{170}$

Recent court decisions apparently carving out an impled exception to sections 206(d) and 514 in family support cases, despite ERISA's broad and specific preemption mandate, have left the state of the law in marital dissolution cases very confused. It is most likely that Congress simply did not consider the issues raised by a potential conflict between ERISA and state domestic relations law. Although Congress did recognize the importance of excepting certain state laws from federal preemption, particularly in the case of welfare plans where pre-

169. Under a defined contribution plan, other than a money purchase plan, an award of benefits to a non-employee spouse could conflict with IRS regulations which require that, in the case of a profit-sharing plan or stock bonus plan, forfeitures under the plan be allocated among the account balances of the other plan participants. Treas. Reg. $\$ 1.401-4$ (a)(1)(iii) (1979). In the case of a inoney purchase plan, forfeitures inay be used to reduce the einployer's contributions to the plan. Treas. Reg. $\S 1.401-7$ (a) (1979). Forfeitures may not inure to the benefit of a terminated or deceased employee but must be allocated to the accounts of the remaining plan participants. Thus an allocation of a portion of a participant's account balance to a non-employee spouse may violate the IRS forfeiture regulations if the employee spouse subsequently forfeits his benefit rights under the plan.

A profit-sharing plan which provides for the withdrawal of accrued vested benefits by a participant who remains in employment may also face unique problems in the event of a court award of benefits to a non-employee spouse. Under Treas. Reg. \$ 1.401-1(b)(i) (1979), a profit-sharing plan could provide for a distribution of benefits upon fulfillment of conditions specified in the plan, such as a showing of hardship by the participant. In the case of an outstanding court order awardiug benefits to a non-employee spouse as of the retirement or termination of employinent of a participant, it is uncertain whether benefits could be distributed to the participant spouse prior to terunimation of employment in accordance with the plan provisions.

170. Thus, for example, in the case of a plan which provides for a complete forfeiture of an employee's accrued vestcd benefit in the event of his death before reaching retirement or early retirement age under the plan, compliance with a court award of benefits that could otherwise have been forfeited by a deceased employee could violate a plan's actuarial assuniptions.

Under ERISA § 302(c)(3) (codified at 29 U.S.C. § 1082(c)(3) (1976)) and I.R.C. § 412(c)(3) a plan must use actuarial assuniptions which are reasonable; the plan's actuary inust make an annual certification as to the reasonableness of the actuarial assuniptions used by the plan under the requirements of ERISA § 103(d)(8) (codified at 29 U.S.C. § 1023(d)(8) (1976)). It is not certain whether a forfeiture of benefits which is based on the life of the non-employee spouse rather than the participant spouse, as in the case of a nonforfeitable future award of benefits pursuant to a court order, could be considered a reasonable actuarial assumption. 
emption would leave a regulatory vacuum, it may not have foreseen the interface between pension plan regulation and state property laws. ${ }^{171}$

We would suggest, therefore, that section 514 of ERISA be amended to save from preemption an application of state law that seeks to enforce familial support obligations. ${ }^{172}$ We recommend that a new section (b)(5) be added to section 514 to read: "(5) This section shall not be construed to supersede the application or enforcement of any state law which imposes a legal obligation to provide child support or to make alimony payments." Pension benefits in pay status would thus be made subject to garnishment or attacliment pursuant to a state court award of either alimony or child support.

Congress should make clear, lowever, that garnishment would not be permissible to accomplish an equitable division of marital property absent a support or alimony decree. It is a garnishment of pension benefits expected to be received, rather than benefits actually in pay status, that does the inost violence to the purposes and specific provisions of ERISA. An attachment of benefits that are no more than a future expectancy gives rise to the dilemma of plan fiduciaries described above. ${ }^{173}$ It is, therefore, not the theory of community property which creates problems for retirement plans, but rather the application of that theory so as to compel a direct payment from a plan to a non-employee spouse who lias no traditionally understood status as a plan participant or beneficiary. ERISA compels a finding of federal preemption of this application of state law.

On the other hand, enforcement of a state support decree poses no such threat to the federal statute's purpose. Support is a concept based

171. The ERISA Improvements Act of I979, S. 209, 96th Cong., 1st Sess., does, however, address specifically the potential conflict between federal pension regulation and state property law which has arisen since the cnactment of ERISA. The bill amends $\S 206$ (d) to exclude from the prohibition of assignment or alienation any marital property decree, alimony or child support judgment which does not require a pension plan to alter the effective date, timing, form, duration or amount of any benefit payments under the plan or to honor any election whicls is not provided under the plan or which is made by a person other than a participant or beneficiary, as defined in ERISA. Section 514 would also be amended to save from preemption domestic relations decrees and alimony or child support orders to the extent permitted by the exception to $\S 206$ (d).

172. It should be noted that this treatment of court orders enforcing the familial support obhgation has already been adopted with respect to Social Security benefits. Section 459 of the Social Security Act permits the garnishment of civil service retirement benefits to enforce court orders for child support and alimony. 42 U.S.C. $\S 659$ (1976) (as amended by Pub. L. No. 95-30, §§ 501(a), 501(b), 91 Stat. 157 (1977)). In 1977, Congress added to the Social Security Act a definitional statute, $\S 462(\mathrm{c})$, which relates to $\S 459$ and limits "alimony" to its traditional meaning of spousal support. That statute states that alimony does not include "any payment or transfer of property or its value by an individual to his spouse or former spouse in compliance with any community property settlement, equitable distribution of property, or other division of property between spouses or former spouses." Pub. L. No. 95-30, Tit. V, § 501(d), 91 Stat. 160 (1977).

173. See text accompanying notes 164-68 supra. 
both on the needs of the beneficiaries of the principal wage earner and on the wage earner's ability to provide those needs. ${ }^{174}$ Thus, the support concept focuses on the present income stream of the principal wage earner. Because the focus of support is on the amount of income received by, or the total wealth of, the principal wage earner, the probleins associated with dividing a property interest of uncertain and potentially fluctuating value are avoided.

Moreover, the human concerns that appear to have motivated the courts that have ruled on the question of retirement plan garnishment in domestic relations cases are not generally present in property settlements. ${ }^{175}$ In marital dissolution actions that do not involve a support or alimony decree, the divorcing parties often are able to allocate expected pension plan benefits that are properly part of the marital estate to the employee spouse, and other assets, sufficient to satisfy the nonemployee spouse's claim to retirement benefits, to the non-employee spouse. ${ }^{176}$

\section{CONCLUSION}

Preemption issues by their very nature require a balancing of state and federal interests. The outcome of that balancing will often depend upon which state interest is cited as the major one against which the

174. The Supreme Court opinion in Hisquierdo also noted the distinction between a support decree and a division of marital property $m$ its discussion of the congressional imtent manifested in the recent ainendments to the Social Security Act:

We know, however, that the purpose of $\S 459$ was to help children and divorced spouses get off welfare. It is therefore logical to conclude that Congress, in adopting $\$$ 462(c), thought that a family's need for support could justify garnishment, even though it deflected other federal benefit programs from their intended goals, but that commumity property claims, which are not based on need, could not do so.

99 S. Ct. at 811.

175. See, for example, the concerns for the welfare of the employee spouse's dependents expressed by courts in Schlaefer v. Schlaefer, 112 F.2d 177 (D.C. Cir. 1940); Cartledge v. Miller, 457 F. Supp. 1146 (S.D.N.Y. 1978); Cogollos v. Cogollos, 93 Misc. 2d 406, 402 N.Y.S.2d 929 (Sup. Ct. 1978); Wanamaker v. Wanamaker, 93 Misc. 2d 784, 401 N.Y.S.2d 702 (Fam. Ct. 1978); and Brown v. Brown, 32 Ohio App. 2d 139, 288 N.E.2d 852 (1972).

See also Stone v. Stone, 450 F. Supp. 919 (N.D. Cal. 1978), an action which reflects many of the compelling characteristics of typical support cases. The divorced spouse in Stone could have brought a traditional support action in lieu of an action to enforce the divorce decree.

176. A number of cases have in fact suggested that a division of property which awards retirement benefits to the employee spouse and other assets to the non-employee spouse is a preferable method of dividing marital property. Thus, for example, the California Supreme Court stated in Phillipson v. Board of Adininistration, 3 Cal. 3d 32, 46, 473 P.2d 765, 774, 89 Cal. Rptr. 61, 70 (1970): "All parties agree, and we concur, that if the community musters sufficient assets to do so, the preferable mode of division would be to award the pension rights to the employee and property of equal value to the spouse." See also In re Marriage of Milhan, 13 Cal. $3 \mathrm{~d} 129,133,528$ P.2d 1145, 1147, 117 Cal. Rptr. 809, 8I1, cert. denied, 421 U.S. 976 (1974); Waite v. Waite, 6 Cal. 3d 461, 473-74, 492 P.2d 13, 21-22, 99 Cal. Rptr. 325 (1972); Bensing v. Bensing, 25 Cal. App. 3d 889, 192 Cal. Rptr. 255 (1972). 
federal interest is balanced.

ERISA is no exception to this rule. Although ERISA appears to give courts a clear statement of both specific preemption language and congressional intent, judicial decisions have shown that further clarification may be needed. While the courts have generally done well in balancing state interests agamst the congressional objectives expressed im ERISA, soine decisions have pointed up the lack of congressional clarity with respect to certain traditional areas of state law. Thus, the insurance proviso and the deemer clause, which appear to deal with the interface between insurance and employee benefit plans, may raise inore questions than they resolve. These issues require a reevaluation of the federal goals expressed in both the McCarran-Ferguson Act and ERISA-a reevaluation and balancing of competing federal policies that should properly be conducted by Congress, not by the courts. The line of cases relating to state pregnancy disability laws raises similar questions under the language of section 514; these, too, should properly be answered by Congress.

In the retirement plan area, most of the cases have dealt with a real or apparent conflict between state and federal laws. The conflict may be only apparent, as in the juxtaposition of community property laws with sections 206(d) and 514 of ERISA, where the "insofar as" language of ERISA, properly interpreted, may be read to preempt only a narrow application of the state law and not the state's broader imterest in division of marital property. The conflict between the language of ERISA and state law may be real, lowever, as im the case of state court support and alimony decrees. The courts have generally reached the just conclusion in these cases, but have been forced to stretch the plain ineaning of the federal statute to do so. Because the result reached by the courts in these cases does violence neither to the administration of ERISA nor to congressional purpose, Congress should give serious consideration to adopting an amendment to ERISA exempting the enforcement of alimony or support obligations from preemption. 